Western North American Naturalist 68(3), (c) 2008, pp. 343-349

\title{
POLYGYNOUS MATING BEHAVIOR IN THE ENDANGERED TEHUANTEPEC JACKRABBIT (LEPUS FLAVIGULARIS)
}

\begin{abstract}
Tamara Rioja ${ }^{1,4}$, Consuelo Lorenzo ${ }^{1}$, Eduardo Naranjo $^{1}$, Laura Scott $^{2}$, and Arturo Carrillo-Reyes ${ }^{3}$
ABSTRACT.-This is the 1st effort to determine the mating behavior of the Tehuantepec jackrabbit (Lepus flavigularis), an endangered endemic species from southern Mexico whose distribution is limited to the Isthmus of Tehuantepec region. Between June 2006 and December 2007, observations of 60 adult radio-marked jackrabbits were carried out in Santa María del Mar, Oaxaca, Mexico. Direct observations showed that the breeding season of the Tehuantepec jackrabbit lasted an average of 200 days per year, with a high-intensity period during the rainy season (May-October); we also confirmed a polygamous reproductive behavior for this species. More importantly, we showed that the Tehuantepec jackrabbit has a polygynous mating behavior. In a single night, a male courted and mounted an average of 2 females; whereas during the whole reproductive season, the male courted an average of 6 females and mounted 3 of them. In a single night, a female was courted by an average of 3 males but mounted by only 1 of them. Throughout the whole reproductive season, the female was courted by 5 males but mounted only by 1 of them. This is the 1 st research concerning mating behavior of the Tehuantepec jackrabbit; the resultant information will be very useful for the jackrabbit's conservation, management, and reproduction in captivity.
\end{abstract}

Key words: Lepus flavigularis, polygyny, polygamy, mating behavior.

Resumen.-Este es el primer esfuerzo para determinar el sistema de apareamiento de la liebre de Tehuantepec (Lepus flavigularis), una especie en peligro de extinción, endémica del sur de México, y cuya distribución se limita a la región del Istmo de Tehuantepec. Se observaron 60 liebres radio-marcadas entre junio del 2006 y diciembre del 2007 en la población de Santa María del Mar, Oaxaca. Observaciones directas mostraron que la época reproductiva de la liebre de Tehuantepec abarcó 200 días, con un período de mayor actividad reproductiva durante la estación húmeda (mayo a octubre). Confirmamos el comportamiento poligámico de la liebre, y más importante, demostramos que la liebre de Tehuantepec posee un sistema de apareamiento de poliginia. En una sola noche, un macho corteja y monta un promedio de 2 hembras, mientras que a lo largo de una misma época reproductiva, el macho corteja un promedio de 6 hembras y monta un promedio de 3. Mientras tanto, en una sola noche, una hembra es cortejada por un promedio de 3 machos pero solo es montada por 1; a lo largo de toda la época reproductiva, la hembra es cortejada por un promedio de 5 machos pero solo es montada por 1. Esta es la primera investigación referente al sistema de apareamiento de la liebre de Tehuantepec; la información generada será de gran utilidad para su conservación, manejo, y reproducción en cautiverio.

Palabras clave: Lepus flavigularis, apareamiento poligínico, apareamiento poligámico.

Polygyny evolves when males gain the greatest reproductive fitness by mating with $>1$ female. Females maximize their reproductive success by 2 strategies: carefully protecting their offspring (maternal care) and choosing males that offer maximum fitness (Orians 1969, Reichard and Boesch 2003). Different levels of polygynous mating behavior are present in different mammal species, from the gorilla (Gorilla gorilla), which has an average of 4 sexual partners, to the marine elephant (or southern elephant seal, Mirounga leonina), which mates with up to 100 females in a single breeding season (Maier 2001). Such differences are a consequence of 4 polygynous mating strategies: resource-defense polygyny, femaledefense polygyny, lek polygyny, and competitive-career polygyny (Bradbury and Gibson 1983, Bronson 1990, Gosling and Petrie 1990, Dunbar 1995, Maier 2001). Reproductive fitness of both sexes, as well as that of the entire population, is assured through suitable genetic flow attributed to the wide distribution of genetic information contained in the sperm of

${ }^{1}$ El Colegio de la Frontera Sur, Departamento de Ecología y Sistemática Terrestres, Carretera Panamericana y Periférico Sur s/n. C.P. 29290, San Cristóbal de Las Casas, Chiapas, México.

${ }^{2}$ Facultad de Ciencias Forestales, Universidad Autónoma de Nuevo León. Carretera Panamericana km 145 s/n, Linares, N.L. México.

${ }^{3}$ E-mail: acarrillo@ecosurmx

${ }^{4}$ Corresponding author. E-mail: trioja@ecosur.mx 


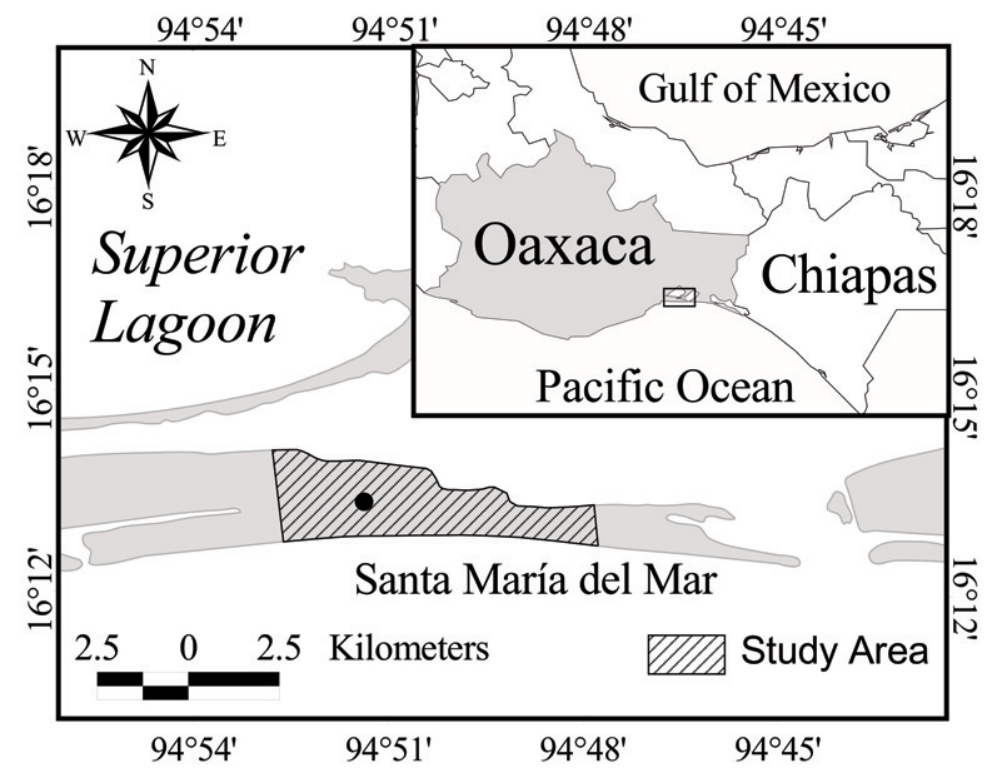

Fig. 1. Study area at Santa María del Mar, southeastern Oaxaca, Mexico.

every male towards the production of numerous progeny, and to the balance of energy expense between the sexes (Maier 2001, MacDonald 2006).

Most species belonging to the genus Lepus are polygynous (Lechleitner 1958, Flux 1981, Nowak 1983, Gray 1989, Flux and Angermann 1990, Kowicz et al. 1990). However, an exception to this rule can be observed in the mountain hare (L. timidus) and the white-tailed jackrabbit (L. townsendii), both of which practice polyandry (Chapman et al. 1982, Corbet and Harris 1991, Angerbojorn and Flux 1995). Monogamy appears among the white-sided jackrabbits (L. callotis), a species closely related to the Tehuantepec jackrabbit (Flux and Angermann 1990).

The Tehuantepec jackrabbit is a Mexican endemic species critically endangered by habitat loss and fragmentation, overhunting, and genetic isolation (Flux and Angermann 1990, Baillie and Groombridge 1996, SEMARNAT 2001). Only 4 small populations of Tehuantepec jackrabbits survive along savannas and grassy dunes on the shores of the Superior and Inferior lagoons, which are bodies of saltwater connected to the Gulf of Tehuantepec in Oaxaca, México (Lorenzo et al. 2006). There are only a few studies on this lagomorph's ecology. Little is known about its habitat use, food habits, and community interactions, or its reproductive behavior and ecology. Nevertheless, Farías et al. (2006) developed a home range study for the Montecillo Santa Cruz population. Even though Farías needed more information, she suggested that the Tehuantepec jackrabbit is polygamous, because the female and male home ranges overlap with more than 1 individual, giving rise to a nonterritorial social organization and increasing the likelihood of promiscuity (Greenwood 1980). Species related to the Tehuantepec jackrabbit, like the blacktailed jackrabbit (L. californicus; Cervantes and Lorenzo 1997), are polygamous and have overlapping home ranges (Lechleitner 1958, Best and Henry 1993). However, the home range can overlap in a monogamous species such as the white-sided jackrabbit, in which pairs share areas of activity (Flux and Angermann 1990, Best and Henry 1993). Assumptions of a polygamous mating behavior in Tehuantepec jackrabbit have not been tested until now.

The main objectives of our research were to generate basic information concerning the reproductive behavior of the Tehuantepec jackrabbit in its habitat and to test the hypothesis that the Tehuantepec jackrabbit is polygamous. This hypothesis was suggested by Farías et al. (2006); however, their results were based on home range overlap studies, whereas this research was conducted through direct 
observations of radio-marked jackrabbits. The information we report will help in understanding the population dynamics of the Tehuantepec jackrabbit and in developing a captive breeding program, which is part of a larger project for management and preservation ("Rescue, Conservation and Management of the Tehuantepec jackrabbit Lepus flavigularis in Oaxaca, México Project," supported by Fondos Mixtos de Apoyo a la Investigación Científica CONACYT-Gobierno del Estado de Chiapas CHIS-2005-C03-001).

\section{STUdy Site}

The study area is located at the southern region of the Isthmus of Tehuantepec in Oaxaca, Mexico. The observed Tehuantepec jackrabbit population is distributed on a 5 -km-long sandy peninsula (Vargas 2000) located between the Laguna Superior and the Gulf of Tehuantepec in the vicinity of the town Santa María del Mar $\left(16^{\circ} 14^{\prime} 12.53^{\prime \prime} \mathrm{N}, \quad 94^{\circ} 57^{\prime} 58.72^{\prime \prime} \mathrm{W}\right.$ and $\left.16^{\circ} 12^{\prime} 15.83^{\prime \prime} \mathrm{N}, 94^{\circ} 45^{\prime} 39.82^{\prime \prime} \mathrm{W}\right)$, municipality Juchitán de Zaragoza. The Tehuantepec jackrabbit population is distributed throughout a 14.33-km² area (Fig. 1).

The climate is tropical and seasonally variable, with a mean annual temperature of $25^{\circ} \mathrm{C}$ and a mean annual rainfall of $800 \mathrm{~mm}$ (García 1964). The rainy season is from May to October with a summer dry spell in August, and the dry season extends from November to April and is severe during late winter and early spring (Zizumbo and Colunga 1982). The vegetation consists mainly of open grasslands located on plains, valleys, and hills characterized by the presence of Jouvea pilosa and zones of xerophitic shrublands, predominantly Opuntia tehuantepecana and O. decumbens (Cervantes 1993, Vargas 2000, Perez-García et al. 2001).

Santa María del Mar has 739 human inhabitants, mostly Huave indigenous people (INEGI 2000, Vargas 2000). Fishing, cattle husbandry, and agriculture constitute the main anthropogenic activities. Cattle graze at approximately 34 feeding places distributed along the grasslands, which are in an area of greater jackrabbit activity (Commissariat of Santa María del Mar personal communication). Both agriculture and cattle husbandry have limited the distribution of the Tehuantepec jackrabbit, because sites for feeding and refuge are eliminated when vegetation is removed (Vargas 2000). Furthermore, poaching is an activity historically carried out in Santa María del Mar. During the rainy season, local hunters arrive from the San Mateo del Mar community and the cities of Salina Cruz and Juchitán to hunt several species, such as armadillo (Dasypus novemcinctus), deer (Odocoileus virginianus), raccoon (Procyon lotor), and mainly the Tehuantepec jackrabbit, for personal consumption or commercial purposes (Vargas 2000, Municipal Agent of Santa María del Mar personal communication). Currently, community authorities protect the Tehuantepec jackrabbit by the surveillance and fining of poachers (Municipal Agent of Santa María del Mar personal communication). However, in the isthmus region, poaching and consumption of terrestrial vertebrates continue to be common activities, because they belong to deep-rooted traditions and are sustained by the impoverished social and economic conditions prevailing in Santa María del Mar (Vargas-Espíndola 2001).

\section{METHODS}

\section{Capture and Handling}

A total of 60 adult jackrabbits (26 males and 34 females) from the Santa María del Mar population were captured using 2 methods: day captures and night captures. During the day, we walked through grasslands and bushy areas in order to direct jackrabbits to a 1-mhigh and 40-m-long fishing net. This method was used in the bushy areas and in the bushgrassland transition zones. At night we drove a pickup truck through grasslands and dunes. Journeys were made through grasslands and along the beach. We located jackrabbits using 2 spotlights, which were attached to the vehicle and which illuminated a distance up to 100 $\mathrm{m}$ away (Lorenzo et al. 2000, Sántiz 2005, Farías et al. 2006). Spotlights were directed on jackrabbits in order to dazzle their vision, and they were then cornered by several people and captured with a handheld fishing net 3-4 $\mathrm{m}$ in diameter. This was a very successful capture method, because it allowed us to minimize handling time and eliminate the threat of injury to the animals (Farías et al. 2006).

Once captured, specimens were immediately transferred from the net to cotton bags for handling. To avoid stressing the animals, we covered the eyes of captured jackrabbits 
with a hood and worked as rapidly as possible. We recorded sex (penis or clitoris visible), weight (hanging scale), body measures (total length, tail length, back-leg length, and ear length; Lechleitner 1958, Adams 1959, Péroux 1995), and age (juvenile or adult). A jackrabbit was considered an adult when it had an approximate weight of $\geq 1.8 \mathrm{~kg}$ and a length of $\geq 55.6 \mathrm{~cm}$, criteria defined by Vorhies and Taylor (1933). Young specimens were measured and then released. All adult jackrabbits were fitted with radio-collars (35 g, 24 months of battery life, activity/mortality sensor, model TX35/24, 148 MHz, TELENAX, Mexico; Lechleitner 1958, Adams 1959, Gray 1989, Kowicz et al. 1990). Our research complied with all current Mexican laws and was conducted under authorization of the Mexican government (Secretaría de Medio Ambiente y Recursos Naturales, Mexico). Capture and handling of jackrabbits followed guidelines approved by the American Society of Mammalogists (Animal Care and Use Committee 1998).

\section{Monitoring}

We intensively radio-tracked Tehuantepec jackrabbits from June 2006 to December 2007. Jackrabbits were radio-located by using portable receivers (148-172 MHz, model R1000, Communications Specialist, Inc., Orange, CA) equipped with 3-element Yagi antennae (TELENAX, México; Farías 2004) and then monitored by direct observation. Also, 25 fixed observation sites distributed throughout the study area were selected. These observation sites were located in key areas (frequently visited areas where congregations of radio-marked jackrabbits had been observed).

To avoid interfering with the jackrabbits' behavior, we made no movements and observed jackrabbits from prudent distances. While we monitored, active jackrabbits continued feeding or interacting socially. We recorded the time (hour and minutes) when the radio-tracked individual was sighted, and then we waited until the jackrabbit walked away before obtaining the universal transverse mercator (UTM) coordinates for the locations of sighting. UTM coordinates were obtained from a GPS handheld receiver (eTrex Vista, 3-15 m accuracy, Garmin, Olathe, KS). We registered jackrabbit activity throughout the 24-hour cycle. Daytime observations were from 06:00 to 19:00, and nighttime observations were from 19:00 to
06:00. We used this definition of day and night both at observation sites and while following radio-marked individuals.

We considered the breeding season as the period of time when males are sexually active and females undergo estrus. We considered males sexually active when they presented prominent black testicles and were observed smelling vulvas of females. Females were identified as being in estrus when they permitted approach of sexually active males (Hoogland, 1998, Hoogland 2001, Boone et al. 2003). We recorded each radio-marked jackrabbit mating by means of direct observation (Gray 1989, Angerbojorn and Flux 1995). Courting and copulating of a radio-marked jackrabbit with $>1$ individual within a single night was considered polygamous mating behavior. If a single male copulated with $\geq 2$ females, the behavior was considered polygyny, whereas if a female copulated with $>1$ male, the behavior was considered polyandry. Copulation of 1 jackrabbit with only 1 individual from the opposite sex within a single night and during the whole reproductive season was considered monogamy. When necessary we used physical characteristics, such as corporal marks (color patterns and spots in the loin hair) to identify jackrabbits that were not radio-marked. We also used previously recorded information about movement area and daily movement patterns to identify rabbits that were not radio-marked (hereafter called “unmarked"; Rioja 2003, Carrillo in preparation). Every observation was carried out using a spotting scope (Leica Televid $^{\mathrm{TM}}$ APO-77 telescope, 20-60X ocular lens) and binoculars (Konus Vue ${ }^{\mathrm{TM}}$, Giant Zoom 10$30 \times 60)$ during the daytime, and night vision oculars (OdisseyTM NON03, 3X, 15000X sensitivity) and halogen lights with red filters for nighttime and crepuscular observations (Lechleitner 1958, Gray 1989, Kowicz et al. 1990, Rioja 2003).

\section{Results}

The Tehuantepec jackrabbit population in Santa María del Mar had a breeding season of 200 days per year. More intense reproductive activity occurred during the rainy season (MaySeptember). A total of 294 courtship events were recorded from June 2006 to December 2007. In 103 of these events, 22 radio-marked males and 33 unmarked females were involved: 
TABLE 1. Average of total courtships and mounts recorded from July 2006 to December 2007. RM = radiomarked male, NRM = non-radio-marked male, $\mathrm{RF}=$ radio-marked female, $\mathrm{NRF}=$ non-radio-marked female.

\begin{tabular}{|c|c|c|c|c|c|c|c|}
\hline & \multirow[b]{2}{*}{$n$} & \multicolumn{2}{|c|}{ Courtship ${ }^{a}$} & \multicolumn{2}{|c|}{ Mounta } & \multirow[b]{2}{*}{ Courtship $^{b}$} & \multirow[b]{2}{*}{ Mounts } \\
\hline & & $\mathrm{RF}$ & $\mathrm{NRF}$ & $\mathrm{RF}$ & $\mathrm{NRF}$ & & \\
\hline Male & 22 & 3 & 3 & 2 & 1 & 6 & 3 \\
\hline Female & 33 & 3 & 2 & 1 & 0.03 & 5 & 1 \\
\hline
\end{tabular}

average of courtship and mount events recorded per individual

bAverage of the total courtship and mount events recorded

64 events occurred between the same 22 radiomarked males and 64 unmarked females, whereas 72 occurred between 33 radio-marked females and 72 unmarked males. These courtship events resulted in mating of 33 radiomarked females and 26 unmarked females.

In all mating events the courtship ritual started with the male approaching 1 or several females submissively. In a submissive approach, a male jackrabbit throws his ears backwards and inclines them, and then he sniffs the female's vulva. If the female is not in estrus or simply does not accept that particular male, then the female rejects the male, pushing him with her forelegs and chasing and biting him until he finally leaves. However, if the female is in estrus and accepts the male, the courtship continues. After mutual sniffing, both male and female turn to face each other and press their chests to the ground; then, the male jumps on the female several times without the female moving. Immediately afterwards, the female imitates the male, and then both return to the original face-to-face position. Afterwards, the male chases the female in circles for some seconds, and sometimes the female turns around and "fights" against the male with her forelegs. Immediately another chase ensues and finally the copulation takes place for up to 1.5 minutes. In $42(14.28 \%)$ of 294 courtship events, we observed a penis display.

Throughout the study (June 2006-December 2007), a radio-marked male courted an average of 6 females ( 3 radio-marked and 3 unmarked) and mounted an average of 3 females ( 2 radio-marked and 1 unmarked; Table 1 ). For every courtship event, a radio-marked male courted an average of 2 females (1 radio-marked and 1 unmarked) and mounted the 2 females ( 1 radio-marked and 1 unmarked).

From June 2006 to December 2007, one radio-marked female was courted by an average of 5 males ( 3 radio-marked and 2 unmarked) and mounted by an average of 1 male (1 radiomarked and 0.03 unmarked; Table 1). For every courtship event registered, 1 radio-marked female was courted by an average of 3 males ( 2 radio-marked and 1 unmarked) and mounted by an average of 1 male (1 radio-marked and 0.02 unmarked).

\section{Discussion}

The breeding season of the Tehuantepec jackrabbit in Santa María del Mar is very similar to that of other leporid species, such as $L$. americanus, L. californicus, L. europeaus, and L. insularis (Banfield 1974, Hewson and Taylor 1975, Godin 1977, Nowak 1983). The increase of reproductive activity during the rainy season suggests a relationship between reproduction and food availability. High intensity rains during the rainy season lead to an increase of vegetation coverage and grassland productivity, which is reflected in more available food for jackrabbits. Likely, the Tehuantepec jackrabbit can spend more energy in reproductive activities during the rainy season, increasing the male's searching for mates and satisfying the female's energy needs for gestation and lactation. A similar relationship occurs for other small and medium-sized mammals (Trivers 1972, Van De Graaff and Balda 1973, Batzli 1986, Bronson 1990), including other jackrabbit species, such as L. californicus, L. europaeus, L. americanus, and L. arcticus (Watson 1954, Leichleitner 1959, Parker 1977, Lochmiller et al. 1982, McClure 1987, O’Donoghue and Krebs 1992).

We observed courtship and mating of individual males with different females throughout a single breeding season, which represents clear evidence of a polygamous mating behavior for the Tehuantepec jackrabbit; we also observed that a female is courted by several males but is mounted only by a dominant male throughout the breeding season. Even more important, we observed the courtship and mating of a male with different females during 1 observation period. Also, we registered mating of a female with just 1 male during 1 observation period. All these observations strongly support a polygynous mating system in the Tehuantepec jackrabbit. These observations about the reproductive behavior of $L$. flavigularis, the lst ever made, agree with the 
hypothesis suggested by Farías et al. (2006) that describes the Tehuantepec jackrabbit as a polygamous species; however, our findings showed that the jackrabbit is not promiscuous, as are other Lepus species (Lechleitner 1958, Flux 1981, Nowak 1983, Gray 1989, Flux and Angermann 1990, Kowicz et al. 1990). Our results show no evidence of polyandry or monogamy in the Tehuantepec jackrabbits.

Information about the reproductive behavior of the Tehuantepec jackrabbit provides fundamental background for development of a management program for this species, because one of the most important conservation strategies is captive breeding. Further research is necessary to describe and understand reproductive rates, care of offspring, and other aspects of the Tehuantepec rabbit's reproductive biology.

\section{ACKNOWLEDGMENTS}

We acknowledge the Consejo Nacional de Ciencia y Tecnología (CONACyT) through the Fondos Mixtos de Apoyo a la Investigación Científica CONACyT-Gobierno del Estado de Chiapas (CHIS-2005-C03-001) for its support of this research. We also thank the municipal and community authorities of Santa María del Mar, Juchitán de Zaragoza, Oaxaca, and especially the Gutierrez Vázquez and Antonio Gutierrez families for their collaboration. We are grateful to many students from El Colegio de la Frontera Sur, Universidad de Ciencias y Artes de Chiapas, and Benemérita Universidad Autónoma de Puebla, for their help during capture efforts. We thank Verónica Farías and Alejandro Campos for their help and suggestions in choosing radio-transmitter characteristics. Finally, we thank Bruce Ferguson and anonymous reviewers for their comments and suggestions that led to improvement of this manuscript.

\section{Literature Cited}

ADAMS, L. 1959. An analysis of a population of snowshoe hares in northwestern Montana. Ecological Monographs 29:141-170.

Angerbojorn, A., And J.E.C. Flux. 1995. Lepus timidus. Mammalian Species 495:1-11.

Animal Care and Use Committee. 1998. Guidelines for the capture, handling, and care of mammals as approved by the American Society of Mammalogists. Journal of Mammalogy 79:1416-1431.

Baillie, J., AND B. Groombridge. 1996. 1996 IUCN Red List of threatened animals. IUCN, Gland, Switzerland. $368 \mathrm{pp}$.
Banfield, A. 1974. Mammals of Canada. University of Toronto Press, Toronto, Ontario, Canada.

Bateman, A.J. 1948. Intra-sexual selection in Drosophila. Heredity 2:349-368.

BatZLI, O.G. 1986. Nutritional ecology of the California vole: effects of food quality on reproduction. Ecology 67:406-412.

Best, T.L., And T.H. Henry. 1993. Lepus callotis. Mammalian Species 442:1-6.

Boone, W.R., M.E. Richardson, and J.A. Greerb. 2003. Breeding behavior of the American black bear Ursus americanus. Theriogenology 60:289-297.

Bradbury, J.W., and R.M. Gibson. 1983. Leks and mate choice. Cambridge University Press, U.K. 348 pp.

BRONSON, F.H. 1990. Mammalian reproductive biology. University of Chicago Press, Chicago, IL. 319 pp.

Cervantes, F.A. 1993. Lepus flavigularis. Mammalian Species 423:1-3.

Cervantes, F.A., And C. Lorenzo. 1997. Morphometric differentiation of rabbits (Sylvilagus and Romerolagus) and jackrabbits (Lepus) of Mexico. Gibier Faune Sauvage 14:405-425.

Chapman, J.A., J.G. Hockman, and W.R. EdWards. 1982. Cottontails. Sylvilagus floridanus and allies. Pages 83-123 in J.A. Chapman and G.A. Feldhamer, editors, Wild mammals of North America. Johns Hopkins University Press, Baltimore, MD.

Dunbar, R.I. 1995. The mating system of callitrichid primates: conditions for coevolution of pair bonding and twinning. Animal Behavior 50:1057-1070.

FARÍAS, V. 2004. Spatio-temporal ecology and habitat selection of the critically endangered tropical hare (Lepus flavigularis) in Oaxaca, México. Doctoral dissertation, University of Massachusetts, Amherst. 121 pp.

Farías, V., T.K. Fuller, F.A. Cervantes, and C. Lorenzo. 2006. Home range and social behavior of the endangered Tehuantepec jackrabbit (Lepus flavigularis) in Oaxaca, México. Journal of Mammalogy 87:748-756.

FLuX, J.E.C. 1981. Reproductive strategies in the genus Lepus. Pages 155-174 in K. Myers and C.D. MacInnes, editors, Proceedings of the World Lagomorph Conference. University of Guelph, Guelph, Ontario, Canada.

Flux, J.E.C., And R. Angermann. 1990. The hares and jackrabbits. Pages 61-94 in J.A. Chapman and J.E.C. Flux, editors, Rabbits, hares and pikas: status survey and conservation action plan. International Union for the Conservation of Nature, Gland, Switzerland.

GarCía, E. 1964. Modificaciones al sistema de clasificación climática de Köpen (para adaptarlo a las condiciones de la República Mexicana). Instituto de Geografía, Universidad Nacional Autónoma de México.

Godin, A.J. 1977. Wild mammals of New England. Johns Hopkins University Press, Baltimore, MD.

Gosling, L.M., And M. Petrie. 1990. Lekking in Topi: a consequence of satellite behavior by small males at hotspots. Animal Behavior 40:272-287.

GRAY, D.R. 1989. Reproductive behavior of arctic hare (Lepus arcticus). Symposium Sur les Stratégies du Comportement. Duschesnay, Quebec.

Greenwood, P.J. 1980. Mating systems, philopatry and dispersal in birds and mammals. Animal Behavior 28:1140-1162.

Hewson, R., and M. TaYlor. 1975. Embryo counts and length of the breeding season in European hares in Scotland from 1960-1972. Acta Theriologica 20:247254. 
Hoogland, J.L. 1998. Philopatry, dispersal, and social organization of Gunnison's prairie dogs. Journal of Mammalogy 80:243-250.

2001. Black-tailed, Gunnison's, and Utah prairie dogs reproduce slowly. Journal of Mammalogy 82 917-927.

[INEGI] Instituto Nacional de Estadística, Geografía e Informática. 2000. XII Censo General de Población y Vivienda 2000. México.

Kowicz, A.B., T.H. Hamilton, D.R. Gray, and C. Downes. 1990. Nursing behavior of arctic hare (Lepus arcticus). Pages 643-664 in C.R. Harington, editor, Canada's missing dimension: science and history in Canadian Arctic Islands, Canadian Museum of Nature, Ottawa, Canada.

Lechleitner, R.R. 1958. Movements, density, and mortality in a black-tailed jackrabbit population. Journal of Wildlife Management 22:371-384.

1959. Sex ratio, age classes and reproduction of the black-tailed jack rabbit. Journal of Mammalogy 40:63-81.

LOChMilLER, R.L., J.B. Wheland, and R.L. KiRKPatrick. 1982. Energetic cost of lactation in Microtus pinetorum. Journal of Mammalogy 63:475-481.

Lorenzo, C., F.A. Cervantes, F. Barragán, and J. VARGAS. 2006. New records of the endangered Tehuantepec jackrabbit (Lepus flavigularis) from Oaxaca, México. Southwestern Naturalist 51:116-119.

Lorenzo, C., O. Retana Guiascón, F.A. Cervantes, J. Vargas, and G.L. Portales. 2000. Status survey of the critically endangered Lepus flavigularis. Final report to the Chicago Zoological Society. El Colegio de la Frontera Sur. San Cristóbal de las Casas, Chiapas, Mexico. 10 pp.

MaCDonald, D. 2006. Evolución, Sociedad y Dimorfismo Sexual. La Gran Enciclopedia de los Mamíferos, Libsa. 927 pp.

MaIER, R. 2001. Sistemas de Apareamiento y Competencia Postcopulatoria. Comportamiento Animal. Un enfoque Evolutivo y Ecológico. McGraw-Hill. 582 pp.

MCCluRE, P.A. 1987. The energetics of reproduction and life histories of cricetine rodents (Neotoma floridana and Sigmodon hispidus). Symposia of the Zoological Society of London 57:241-258.

NOWAK, R.M. 1983. Walker's mammals of the world. 4th edition. Johns Hopkins University Press, Baltimore, MD. 2015 pp.

O’Donoghue, M., And C.J. Krebs. 1992. Effects of supplemental food on snowshoe hare reproduction and juvenile growth at a cyclic population peak. Journal of Animal Ecology 61:631-641.

OrIans, G.H. 1969. On the evolution of mating systems in birds and mammals. American Naturalist 103:589603.

ParkeR, G.R. 1977. Morphology, reproduction, diet, and behavior of the arctic hare (Lepus arcticus monstra- bilis) on Axel Heiberg Island, Northwest Territories. Canadian Field-Naturalist 91:8-18.

Pérez-García, E.A., J. Meave, and C. Gallardo. 2001. Vegetación y Flora de la Región de Nizanda, Istmo de Tehuantepec, Oaxaca, México. Acta Botánica Mexicana 56:19-88.

PÉroux, R. 1995. Le liévre d'Europe. Bulletin Mensuel de l'Office National de la Chasse 204:1-96.

Reichard, U.H., and C. Boesch. 2003. Monogamy: mating strategies and partnerships in birds, humans and other mammals. Cambridge University Press, U.K. $267 \mathrm{pp}$.

RiojA, T. 2003. Comportamiento Reproductivo del Perrito Llanero Mexicano (Cynomys mexicanus Merriam) en el Altiplano Mexicano. Master's thesis, UANL México. $91 \mathrm{pp}$.

SánTiZ, E. 2005. Selección de Hábitat y Densidad de la Liebre del Istmo Lepus flavigularis (Wagner 1844) en Oaxaca, México. Master's thesis, Instituto de Ecología, A.C. México. 89 pp.

[SEMARNAT] SEcretaría de Medio AMbiente y Recursos Naturales. 2001. Norma Oficial Mexicana NOM059-ECOL-2001. Protección ambiental-especies nativas de México de flora y fauna silvestres-categorías de riesgo y especificaciones para su inclusión, exclusión o cambio-lista de especies en riesgo. Diario Oficial de la Federación, 1:1-22.

Trivers, R.L. 1972. Parental investment and sexual selection. Campbell, Chicago, IL.

Van De Graaff, K.M., and R.P. BaLDa. 1973. Importance of green vegetation for reproduction in the kangaroo rat, Dipodomys merriami merriami. Journal of Mammalogy 54:509-512.

VARGAS, C. 2000. Distribución, Abundancia y Hábitat de la Liebre Endémica Lepus flavigularis (Mammalia: Lagomorpha). Master's thesis, Facultad de Ciencias, UNAM, México, D.F. 70 pp.

VARGAS-ESPínDOLA, Z.F. 2001. Valoración de los Vertebrados Terrestres por Huaves y Zapotecas del Istmo de Tehuantepec, Oaxaca, México. Master's thesis, El Colegio de la Frontera Sur, SCLC, Chiapas, México.

Vorhies, C.T., AND W.P. TaYlor. 1933. The life histories and ecology of jack rabbits Lepus alleni and Lepus californicus ssp. in relation to grazing in Arizona. University of Arizona Agriculture Experiment Station, Technical Bulletin, 49:471-587.

Watson, J.S. 1954. Breeding season of the wild rabbit in New Zealand. Nature 174:608.

Zizumbo, D., And P. Colunga. 1982. Los Huaves. La apropiación de los recursos naturales. Universidad Autónoma Chapingo, Texcoco, Estado de México.

Received 8 July 2007 Accepted 6 March 2008 